\title{
Clinicopathological features of small cell carcinoma of the uterine cervix in the surveillance, epidemiology, and end results database
}

\author{
Juan Zhou ${ }^{1, *}$, San-Gang Wu ${ }^{2, *}$, Jia-Yuan Sun ${ }^{3, *}$, Li-Ying Tang ${ }^{4}$, Huan-Xin Lin ${ }^{3}$, Feng- \\ Yan $\mathrm{Li}^{3}$, Qiong-Hua Chen ${ }^{1}$, Xin Jin ${ }^{5}$ and Zhen-Yu He ${ }^{3}$ \\ ${ }^{1}$ Department of Obstetrics and Gynecology, The First Affiliated Hospital of Xiamen University, Xiamen, People's Republic of \\ China \\ ${ }^{2}$ Department of Radiation Oncology, Xiamen Cancer Hospital, The First Affiliated Hospital of Xiamen University, Xiamen, \\ People's Republic of China \\ ${ }^{3}$ Department of Radiation Oncology, Sun Yat-sen University Cancer Center, State Key Laboratory of Oncology in South China, \\ Collaborative Innovation Center of Cancer Medicine, Guangzhou, People's Republic of China \\ ${ }^{4}$ Eye Institute of Xiamen University, Fujian Provincial Key Laboratory of Ophthalmology and Visual Science, Medical College \\ of Xiamen University, Xiamen, People's Republic of China \\ ${ }^{5}$ Faculty of Basic Medicine, Medical College, Xiamen University, Xiamen, People's Republic of China \\ *These authors have contributed equally to this work \\ Correspondence to: Xin Jin, email: xinjin@xmu.edu.cn \\ Zhen-Yu He, email: hezhy@sysucc.org.cn
}

Keywords: cervical carcinoma, small cell, survival, prognosis

Received: June 06, $2016 \quad$ Accepted: March 03, 2017

Published: March 21, 2017

Copyright: Zhou et al. This is an open-access article distributed under the terms of the Creative Commons Attribution License 3.0 (CC BY 3.0), which permits unrestricted use, distribution, and reproduction in any medium, provided the original author and source are credited.

\section{ABSTRACT}

To investigate the clinicopathological characteristics and survival of small cell carcinoma of the cervix using Surveillance, Epidemiology, and End Results database. Patients with a diagnosis of small cell carcinoma of the cervix were included between 1988 and 2012. Kaplan-Meier method and Cox regression models were used. A total of 487 patients were included. Of the patients with known International Federation of Gynecology and Obstetrics stage and tumor grade, the stage IV disease was diagnosed in $\mathbf{3 7 . 9} \%$ patients, and $\mathbf{9 8 . 5} \%$ patients had poorly or undifferentiated histology. The 5-year cause specific survival and overall survival were $33.0 \%$ and $\mathbf{2 9 . 4 \%}$, respectively. In multivariate analysis, increasing age, advanced stage, and treatment by primary radiotherapy were associated with worse survival outcomes. Small cell carcinoma of the cervix is a rare disease with aggressive characteristics and prone to metastasize and is dismal in prognosis. Reduced survival was associated with increasing age, advanced stage, and treatment by primary radiotherapy.

\section{INTRODUCTION}

According to the National Cancer Institute, there were approximately 12,900 new cases diagnosed and 4,100 deaths due to cervix cancer in 2015 [1]. About 90\% of cervical cancer patients are squamous cell carcinoma. Small cell carcinoma of the cervix (SCCC) is a rare disease accounting for approximately $2-5 \%$ of uterine cervix malignancies [2-4].

SCCC was first reported by Reagan et al. in 1957 [5]. Like small cell carcinoma in other body sites, SCCC is highly invasive and prone to distant metastatic spread $[3,4,6-8]$, causing poorer prognosis than other types of cervical cancer. The 5-year survival rates vary from $0 \%$ to $51 \%$ of patients with SCCC [8-11]. However, the clinicopathological features and biological behavior of SCCC in above studies were including limited number of patients. The aims of this study were to investigate the clinicopathological characteristics and survival in patients with SCCC using Surveillance, Epidemiology, and End Results (SEER) database. 
Table 1: Patient characteristics

\begin{tabular}{|c|c|}
\hline Variable & n $(\%)$ \\
\hline \multicolumn{2}{|l|}{ Age (years) } \\
\hline Median (Range) & $49(19-95)$ \\
\hline $19-29$ & $59(12.1)$ \\
\hline $30-39$ & $85(17.5)$ \\
\hline $40-49$ & $115(23.6)$ \\
\hline $50-59$ & $85(17.5)$ \\
\hline $60-69$ & $72(14.8)$ \\
\hline $70-79$ & $47(9.7)$ \\
\hline $80+$ & $24(4.8)$ \\
\hline \multicolumn{2}{|l|}{ Race } \\
\hline Black & $66(13.6)$ \\
\hline White & $347(71.3)$ \\
\hline Other and unknown & $74(15.1)$ \\
\hline \multicolumn{2}{|l|}{ Marital status } \\
\hline No & $212(45.2)$ \\
\hline Yes & $257(54.8)$ \\
\hline Unknown & 18 \\
\hline \multicolumn{2}{|l|}{ FIGO Stage } \\
\hline IA & $33(7.2)$ \\
\hline IB & $82(17.9)$ \\
\hline I NOS & $5(1.1)$ \\
\hline IIA & $12(2.6)$ \\
\hline IIB & $28(6.1)$ \\
\hline IIIA & $10(2.2)$ \\
\hline IIIB & $113(24.7)$ \\
\hline III NOS & $1(0.2)$ \\
\hline IVA & $9(2.0)$ \\
\hline IVB & $163(35.7)$ \\
\hline IV NOS & $1(0.2)$ \\
\hline Unknown & 30 \\
\hline \multicolumn{2}{|l|}{ Grade } \\
\hline Well differentiated & $1(0.3)$ \\
\hline $\begin{array}{l}\text { Moderately } \\
\text { differentiated }\end{array}$ & $4(1.2)$ \\
\hline $\begin{array}{l}\text { Poorly/ } \\
\text { undifferentiated }\end{array}$ & $326(98.5)$ \\
\hline
\end{tabular}

\begin{tabular}{lc}
\hline Variable & $\mathbf{n}(\mathbf{\%})$ \\
\hline Unknown & 156 \\
Tumor size & \\
Median size $(\mathrm{cm})$ & $5.5(0.2-21.0)$ \\
(range) & $95(34.5)$ \\
$\leq 4$ cm & $180(65.5)$ \\
$>4$ cm & 212 \\
Unknown & $112(24.2)$ \\
SEER stage & $180(39.0)$ \\
Localized & $170(36.8)$ \\
Regional & 25 \\
Distant & $149(31.4)$ \\
Unknown & $71(47.7)$ \\
Local treatment modalities & $164(44.4)$ \\
Hysterectomy \pm & \\
radiotherapy & \\
Radiotherapy & \\
Unknown & \\
Nymphadenectomy & \\
Yes & \\
\hline
\end{tabular}

Abbreviations: FIGO, International Federation of Gynecology and Obstetrics; SEER, Surveillance Epidemiology and End Results.

\section{RESULTS}

\section{Demographic, clinicopathological, and treatment characteristics}

SEER database included 107,618 patients with small cell carcinoma and 65,761 patients with cervix cancer from 1988 to 2012. We included 487 patients with SCCC and a median age of 49 years (range, 1995 years). The demographic, clinicopathological, and treatment characteristics are depicted in Table 1. The incidence of SCCC differed significantly according to age group. Patients with ages 40-49 years had a much higher incidence.

(Continued) 
A total of 457 patients with International Federation of Gynecology and Obstetrics (FIGO) stage was available, 120 patients $(26.3 \%)$ had stage I disease, 40 patients $(8.8 \%)$ in FIGO stage II, 124 patients $(27.1 \%)$ in stage III, and 173 patients $(37.9 \%)$ in stage IV. Of the 331 patients with known histologic grade, 326 (98.5\%) had tumors with poorly/undifferentiated grade. According to SEER stage $(\mathrm{n}=462), 112(24.2 \%)$ patients had localized stage, $180(39.0 \%)$ had regional stage, and 170 (36.8\%) had distant stage. A total of 275 patients with known tumor size, $180(65.5 \%)$ had tumor size $>4 \mathrm{~cm}$ (Table 1$)$.

Of the 369 patients with known local treatment modalities including hysterectomy and radiotherapy, 74 patients $(20.1 \%)$ were treated with primary hysterectomy, 90 (24.4\%) patients received hysterectomy and radiotherapy, and 205 (55.6\%) patients received primary radiotherapy. A total of 149 patients received lymphadenectomy, and $78(52.3 \%)$ of them were nodepositive disease (Table 1).

\section{Survival}

Median survivals along with 5-year cause-specific survival (CSS) and overall survival (OS) for SCCC are summarized in Table 2. Mortality increased rapidly in the three years following diagnosis. Figure 1A shows the CSS of the SCCC patients. The 1-, 3-, 5-, and 10-year CSS was $61.6 \%, 37.3 \%, 33.0 \%$, and $22.9 \%$, respectively. The $1-, 3-$, 5 -, and 10 -year OS was $60.4 \%, 34.7 \%, 29.4 \%$, and $26.3 \%$, respectively (Figure 1B). Patients with younger age, nonblack racial status, married status, early stage, localized stage, node-negative tumors, and treatment with surgery \pm radiotherapy had better CSS and OS (all $P<0.05$ ). No differences in CSS and OS were observed among tumor grades and tumor size.

\section{Prognostic factors}

Age at diagnosis, race, marital status, SEER stage, FIGO stage, lymph node status, and local treatment modalities were significant prognostic factors for CSS and OS by univariate analysis, whereas tumor size and tumor grade were not (Table 3).

A stepwise multivariable analysis of variables that were significant by univariate analysis showed that increasing age (CSS: hazard ratio [HR] 1.016, 95\% confidence interval [CI] 1.008-1.025, $P=0.001$; OS: HR 1.019, 95\%CI 1.011-1.027, $P<0.001)$, advanced FIGO stage (CSS: HR 1.579, 95\%CI 1.383-1.802, $P<0.001$; OS: HR $1.545,95 \%$ CI $1.362-1.752, P<0.001)$ and treatment by primary radiotherapy (CSS: HR $1.873,95 \%$ CI 1.399 2.508, $P<0.001$; OS: HR 1.854, 95\%CI 1.402-2.452, $P<$ $0.001)$ were significantly related to inferior CSS and OS (Table 4). Figure 2 shows CSS and OS according to FIGO stage.
We further analyzed the prognostic factors for patients who underwent hysterectomy and lymphadenectomy. As adjusted for age, race, marital status, SEER stage, lymph node status, and local treatment strategies, advanced FIGO stage (CSS: HR 1.365, 95\%CI 1.060-1.757, $P=0.016$; OS: HR 1.316, 95\%CI 1.030-1.680, $P=0.028$ ) and local treatment modalities (hysterectomy and radiotherapy vs. hysterectomy) (CSS: HR 1.928, 95\%CI 1.081-3.437, $P=0.026$; OS: HR 1.942, 95\%CI 1.106-3.412, $P=0.021)$ were still the independent prognostic factors of survival. The lymph node status has no effect on survival outcome in patients received lymphadenectomy.

\section{DISCUSSION}

Most of the knowledge in the SCCC comes from single-institution reports with a limited numbers of patients [12-14]. Here, we identified 487 patients of histologically confirmed SCCC between 1988 and 2012 from the SEER registry. Previous studies have showed that SCCC accounts for $2-5 \%$ of all cervix cancers [2-4]. The incidence rate in our study was $0.7 \%$, which is lower than previously reported. About $98.5 \%$ of SCCC patients have poorly or undifferentiated histology. Therefore, it is important to distinguish SCCC from poorly differentiated cervical cancer.

No prospective data was available to compare surgery with primary radiotherapy for resectable SCCC. Chen et al. previously reported a lower locoregional failure rate in patients who received primary radiotherapy than those who had primary surgery in stage I-II SCCC (6\% vs. $27 \%, P=0.009$ ) [15]. Cohen et al. found that the OS (38.2\% vs. $23.8 \%)$ was improved in patients who received radical hysterectomy $(68.1 \%$ and $26.7 \%$ of patients underwent surgery in stage I-IIA and IIB-IVA diseases, respectively) [8]. In our previous study, we have found that radical surgery was the effective treatment for stage I-II SCCC [16]. In the present study, patients receiving surgery \pm radiotherapy had better survival than those treated with primary radiotherapy. This difference may be partially explained that patients receiving surgery are usually diagnosed with stage I-II SCCC and those undergoing primary radiotherapy are often diagnosed as stage III-IV SCCC. Although surgery remains an important modality for early stage SCCC, chemotherapydominant comprehensive therapy is considered the main treatment for patients with advanced SCCC [3, 4].

In this study, FIGO stage was also significantly related to survival of SCCC patients. Several studies have found that patients with advanced stage were associated with poor survival [11, 17-19]. A total of $37.9 \%$ of patients had stage IV disease at the initial diagnosis in this study. In other studies, 4.6-23.5\% of patients had stage IV SCCC at the initial diagnosis $[6,11,20]$. The discrepancy in the proportion of patients with stage IV SCCC might be ascribed to the sample size. A worse survival outcome 
Table 2: Median, 5-year cause-specific survival and overall survival

\begin{tabular}{|c|c|c|c|c|c|c|}
\hline \multirow[t]{2}{*}{ Variable } & \multicolumn{3}{|c|}{ CSS } & \multicolumn{3}{|c|}{$\mathbf{O S}$} \\
\hline & $\begin{array}{c}\text { Median survival } \\
\text { (months) }\end{array}$ & 5-year & P value & $\begin{array}{l}\text { Median survival } \\
\text { (months) }\end{array}$ & 5-year & Pvalue \\
\hline \multicolumn{7}{|l|}{ Age(years) } \\
\hline 19-29 & 60 & 50.2 & $<0.001$ & 57 & 48.3 & $<0.001$ \\
\hline $30-39$ & 29 & 40.6 & & 29 & 40.6 & \\
\hline $40-49$ & 26 & 40.1 & & 23 & 35.9 & \\
\hline $50-59$ & 19 & 32.9 & & 18 & 26.4 & \\
\hline $60-69$ & 10 & 16.4 & & 10 & 14.2 & \\
\hline $70-79$ & 9 & 16.0 & & 9 & 9.0 & \\
\hline $80+$ & 5 & 12.5 & & 5 & 12.5 & \\
\hline \multicolumn{7}{|l|}{ Race } \\
\hline White & 18 & 32.8 & 0.032 & 18 & 30.4 & 0.009 \\
\hline Black & 13 & 23.2 & & 11 & 16.9 & \\
\hline Other and unknown & 29 & 42.0 & & 27 & 36.5 & \\
\hline \multicolumn{7}{|l|}{ Marital status } \\
\hline No & 16 & 29.5 & 0.033 & 15 & 25.7 & 0.011 \\
\hline Yes & 25 & 37.7 & & 22 & 35.0 & \\
\hline \multicolumn{7}{|l|}{ FIGO stage } \\
\hline I & 240 & 60.7 & $<0.001$ & 125 & 55.2 & $<0.001$ \\
\hline II & 29 & 40.3 & & 29 & 40.3 & \\
\hline III & 25 & 31.3 & & 24 & 28.5 & \\
\hline IV & 8 & 12.1 & & 7 & 9.0 & \\
\hline \multicolumn{7}{|l|}{ Grade } \\
\hline $\begin{array}{l}\text { Well/ moderately } \\
\text { differentiated }\end{array}$ & 17 & 20.0 & 0.581 & 17 & 20.0 & 0.697 \\
\hline $\begin{array}{l}\text { Poorly/ } \\
\text { undifferentiated }\end{array}$ & 21 & 34.0 & & 19 & 30.5 & \\
\hline \multicolumn{7}{|l|}{ Tumor size } \\
\hline$\leq 4 \mathrm{~cm}$ & 31 & 37.7 & 0.101 & 26 & 32.7 & 0.128 \\
\hline$>4 \mathrm{~cm}$ & 20 & 35.1 & & 19 & 32.9 & \\
\hline \multicolumn{7}{|l|}{ SEER stage } \\
\hline Localized & 240 & 60.1 & $<0.001$ & 125 & 55.0 & $<0.001$ \\
\hline Regional & 26 & 34.1 & & 25 & 31.2 & \\
\hline Distant & 7 & 12.6 & & 7 & 9.3 & \\
\hline \multicolumn{7}{|l|}{ Nodal status } \\
\hline Node negative & - & 62.7 & 0.002 & - & 59.5 & 0.002 \\
\hline Node positive & 27 & 38.5 & & 26 & 35.6 & \\
\hline \multicolumn{7}{|l|}{$\begin{array}{l}\text { Local treatment } \\
\text { modalities }\end{array}$} \\
\hline $\begin{array}{l}\text { Hysterectomy } \pm \\
\text { radiotherapy }\end{array}$ & 96 & 52.0 & $<0.001$ & 57 & 49.0 & $<0.001$ \\
\hline Radiotherapy & 15 & 24.0 & & 15 & 20.1 & \\
\hline
\end{tabular}

Abbreviations: CSS, cause-specific survival; FIGO, International Federation of Gynecology and Obstetrics; OS, overall survival; SEER, Surveillance Epidemiology and End Results. 
was also associated with increasing age on multivariate analysis. In patients with non-specific pathological type of cervical cancer, the poor prognoses associated with increasing age have been reported in our previous studies $[21,22]$. However, age had no significant prognostic value in other studies with SCCC subtype $[8,9,11,23]$.

It has been reported that the incidence of lymph nodes metastasis vary from $39.4 \%$ to $70 \%$ of SCCC patients who receive lymph node resection [9, 11, 23], which was significantly higher than that in patients with squamous cell carcinoma and adenocarcinoma of the cervix [24, 25]. However, the prognostic role of nodal status in SCCC remains controversial. We found that $52.3 \%$ of SCCC patients had node-positive, and univariate analysis indicated that patients with positive lymph nodes had a poorer prognosis. However, multivariate analysis failed to identify lymph node status as a prognostic factor. Our findings were consistent with two retrospective studies by Liao et al. $(\mathrm{n}=293)$ [23] and Wang et al. $(\mathrm{n}=179)$ [11] with a relatively large number of patients. Therefore, more studies are warranted in the future to assess the prognostic value of lymph node status in SCCC patients.

The treatment modalities of SCCC and small-cell lung cancer are similar due to similar biological behavior including lymph node involvement, vascular invasion, and early recurrence [26-28]. Chemotherapy is an important component of multimodality therapy. Several studies have found that concurrent chemotherapy or adjuvant chemotherapy improved survival in SCCC [7, 8, 15, $29,30]$. In this study, we cannot analyze the effect of chemotherapy on the survival of SCCC patients due to

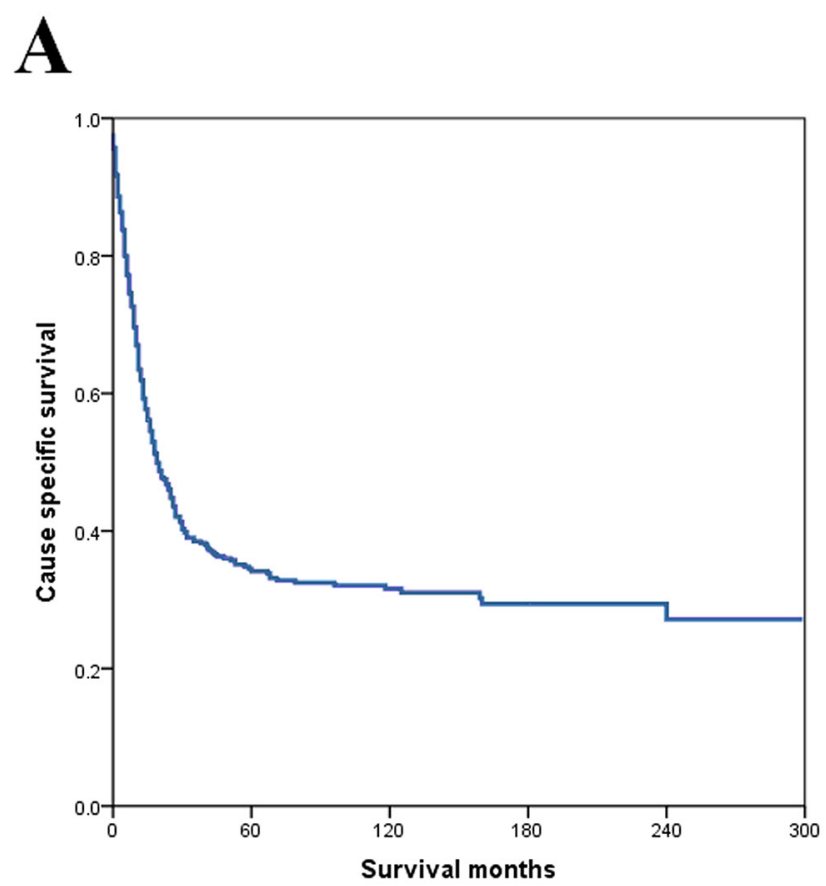

the limitations of SEER database. The British Columbia Cancer Agency began using multimodality regimen including platinum-based chemotherapy in the treatment of SCCC in 1989 [7]. Several studies also showed that most of patients received multimodality therapeutic strategies including chemotherapy regimens after 1990 [11, 17, 29, 30]. We included patients between 1988 and 2012, who were in a chemotherapy-based treatment era, and the survival rates of different FIGO stage in our study were similar to those of previous studies [11, 17, 29, 30]. The SEER-Medicare database contains the chemotherapy data. However, only patients with 65 years or older were included in the SEER-Medicare database, which will significantly reduce the sample size and limit the generalizability of the study (101 patients older than 65 years in the present study).

The pathological factors including surgery margin, lymphovascular invasion and parametrial invasion are the prognostic factors of cervical cancer. SEER program also lacks the information of the above pathological factors. The prognostic value of above pathological factors in SCCC remains controversial. A study be Wang et al. showed that positive surgical margins was an adverse prognostic factor for failure-free survival $(P<0.001)$ but not in cancer-specific survival $(P=0.593)$, lymphovascular invasion and parametrial extension had no effect of survival in multivariate analyses [11]. However, the other two studies did not report the prognostic value of surgical margin on survival $[9,15]$. Lymphovascular invasion and parametrial involvement were also found to have no prognostic value in SCCC $[8,15,23]$. Therefore,

\section{B}

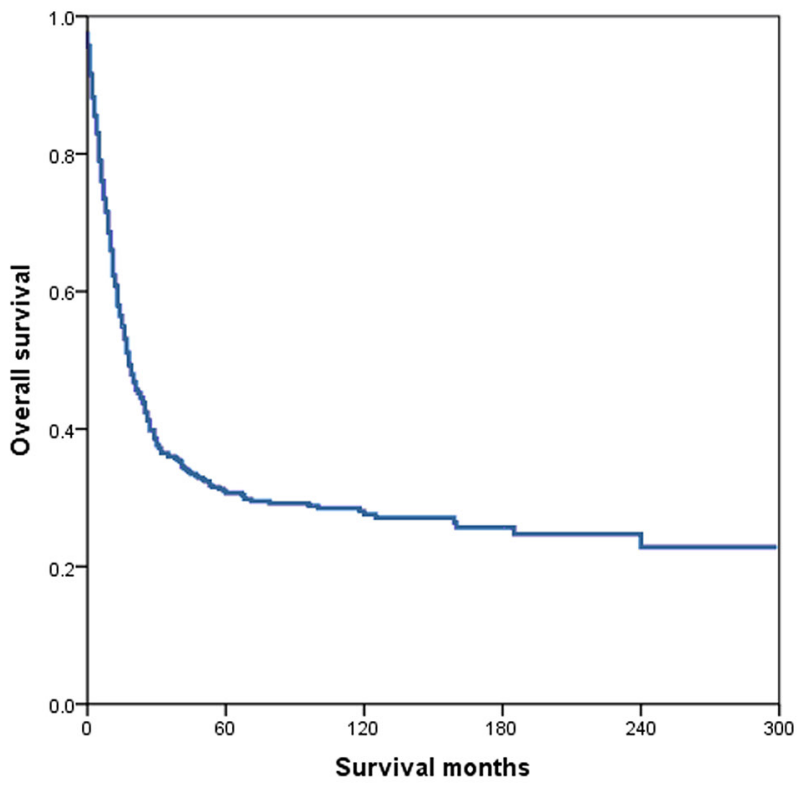

Figure 1: Cause-specific survival (A) and overall survival (B) for all patients. 
Table 3: Univariate analysis of cause-specific survival and overall survival

\begin{tabular}{|c|c|c|c|c|c|c|}
\hline \multirow[t]{2}{*}{ Variable } & \multicolumn{3}{|c|}{ CSS } & \multicolumn{3}{|c|}{ OS } \\
\hline & HR & $95 \%$ CI & Pvalue & HR & $95 \%$ CI & P value \\
\hline $\begin{array}{l}\text { Age (years) } \\
\text { (continuous variable) }\end{array}$ & 1.024 & $1.017-1.031$ & $<0.001$ & 1.026 & $1.019-1.033$ & $<0.001$ \\
\hline \multicolumn{7}{|l|}{ Race } \\
\hline White & 1 [Reference] & & & 1 [Reference] & & \\
\hline Black & 1.351 & $0.982-1.858$ & 0.064 & 1.477 & $1.095-1.993$ & 0.011 \\
\hline Other & 0.770 & $0.553-1.071$ & 0.121 & 0.807 & $0.590-1.105$ & 0.182 \\
\hline \multicolumn{7}{|l|}{ Marital status } \\
\hline No & 1 [Reference] & & & 1 [Reference] & & \\
\hline Yes & 0.781 & $0.619-0.984$ & 0.036 & 0.752 & $0.601-0.940$ & 0.012 \\
\hline \multicolumn{7}{|l|}{ FIGO stage } \\
\hline I & 1 [Reference] & & & 1 [Reference] & & \\
\hline II & 1.663 & $1.011-2.734$ & 0.045 & 1.492 & $0.925-2.408$ & 0.101 \\
\hline III & 2.229 & $1.549-3.207$ & $<0.001$ & 2.087 & $1.478-2.938$ & $<0.001$ \\
\hline IV & 5.522 & $3.927-7.764$ & $<0.001$ & 5.213 & $3.781-7.187$ & $<0.001$ \\
\hline \multicolumn{7}{|l|}{ Grade } \\
\hline $\begin{array}{l}\text { Well/ moderately } \\
\text { differentiated }\end{array}$ & 1 [Reference] & & & 1 [Reference] & & \\
\hline $\begin{array}{l}\text { Poorly/ } \\
\text { undifferentiated }\end{array}$ & 0.760 & $0.282-2.047$ & 0.588 & 0.824 & $0.306-2.218$ & 0.702 \\
\hline \multicolumn{7}{|l|}{ SEER stage } \\
\hline Localized & 1 [Reference] & & & 1 [Reference] & & \\
\hline Regional & 1.999 & $1.414-2.827$ & $<0.001$ & 1.961 & $1.413-2.722$ & $<0.001$ \\
\hline Distant & 5.324 & $3.767-7.523$ & $<0.001$ & 5.153 & $3.707-7.163$ & $<0.001$ \\
\hline \multicolumn{7}{|l|}{ Tumor size } \\
\hline$\leq 4 \mathrm{~cm}$ & 1 [Reference] & & & 1 [Reference] & & \\
\hline$>4 \mathrm{~cm}$ & 1.312 & $0.944-1.823$ & 0.106 & 1.272 & $0.929-1.740$ & 0.133 \\
\hline \multicolumn{7}{|l|}{ Nodal status } \\
\hline Node negative & 1 [Reference] & & & 1 [Reference] & & \\
\hline Node positive & 2.066 & $1.278-3.342$ & 0.003 & 2.050 & $1.288-3.262$ & 0.002 \\
\hline \multicolumn{7}{|l|}{$\begin{array}{l}\text { Local treatment } \\
\text { modalities }\end{array}$} \\
\hline $\begin{array}{l}\text { Hysterectomy } \pm \\
\text { radiotherapy }\end{array}$ & 1 [Reference] & & & 1 [Reference] & & \\
\hline Radiotherapy & 2.292 & $1.734-3.209$ & $<0.001$ & 2.304 & $1.765-3.009$ & $<0.001$ \\
\hline
\end{tabular}

Abbreviations: CI, confidence interval; CSS, cause-specific survival; FIGO, International Federation of Gynecology and Obstetrics; HR, hazard ratio; OS, overall survival; SEER, Surveillance Epidemiology and End Results.

there were different prognostic factors in SCCC compared to squamous cell carcinoma and adenocarcinoma of the uterine cervix.
There are several limitations of this study. The first is the inherent biases existing in any retrospective study. However, the major strength of the present study is the ability to describe the epidemiology, clinicopathological 
Table 4: Multivariate analyses of cause-specific survival and overall survival

\begin{tabular}{|c|c|c|c|c|c|c|}
\hline \multirow[t]{2}{*}{ Variable } & \multicolumn{3}{|c|}{ CSS } & \multicolumn{3}{|c|}{ OS } \\
\hline & HR & $95 \% \mathrm{CI}$ & Pvalue & HR & $95 \% \mathrm{CI}$ & P value \\
\hline \multicolumn{7}{|l|}{ Entire group } \\
\hline $\begin{array}{l}\text { Age (years) (continuous } \\
\text { variable) }\end{array}$ & 1.016 & $1.008-1.025$ & $<0.001$ & 1.019 & $1.011-1.027$ & $<0.001$ \\
\hline Race & - & - & - & 0.953 & $0.794-1.143$ & 0.602 \\
\hline Marital status & 1.160 & $0.871-1.545$ & 0.310 & 1.100 & $0.835-1.449$ & 0.499 \\
\hline FIGO stage & 1.579 & $1.383-1.802$ & $<0.001$ & 1.545 & $1.362-1.752$ & $<0.001$ \\
\hline SEER stage & 0.817 & $0.542-1.620$ & 0.817 & 0.951 & $0.564-1.605$ & 0.852 \\
\hline $\begin{array}{l}\text { Local treatment } \\
\text { modalities }\end{array}$ & 1.873 & $1.399-2.508$ & $<0.001$ & 1.854 & $1.402-2.452$ & $<0.001$ \\
\hline \multicolumn{7}{|l|}{ With lymphadenectomy } \\
\hline Age & 1.007 & $0.987-1.027$ & 0.517 & 1.008 & $0.988-1.028$ & 0.451 \\
\hline Race & - & - & - & 1.178 & $0.836-1.659$ & 0.348 \\
\hline Marital status & 0.818 & $0.473-1.417$ & 0.476 & 0.903 & $0.528-1.546$ & 0.710 \\
\hline FIGO stage & 1.365 & $1.060-1.757$ & 0.016 & 1.316 & $1.030-1.680$ & 0.028 \\
\hline SEER stage & 0.548 & $0.100-2.992$ & 0.487 & 0.475 & $0.088-2.579$ & 0.389 \\
\hline Nodal status & 0.911 & $0.237-3.497$ & 0.892 & 0.886 & $0.232-3.378$ & 0.859 \\
\hline Adjuvant radiotherapy & 1.928 & $1.081-3.437$ & 0.026 & 1.942 & $1.106-3.412$ & 0.021 \\
\hline
\end{tabular}

Abbreviations: CI, confidence interval; CSS, cause-specific survival; FIGO, International Federation of Gynecology and Obstetrics; HR, hazard ratio; OS, overall survival; SEER, Surveillance Epidemiology and End Results.
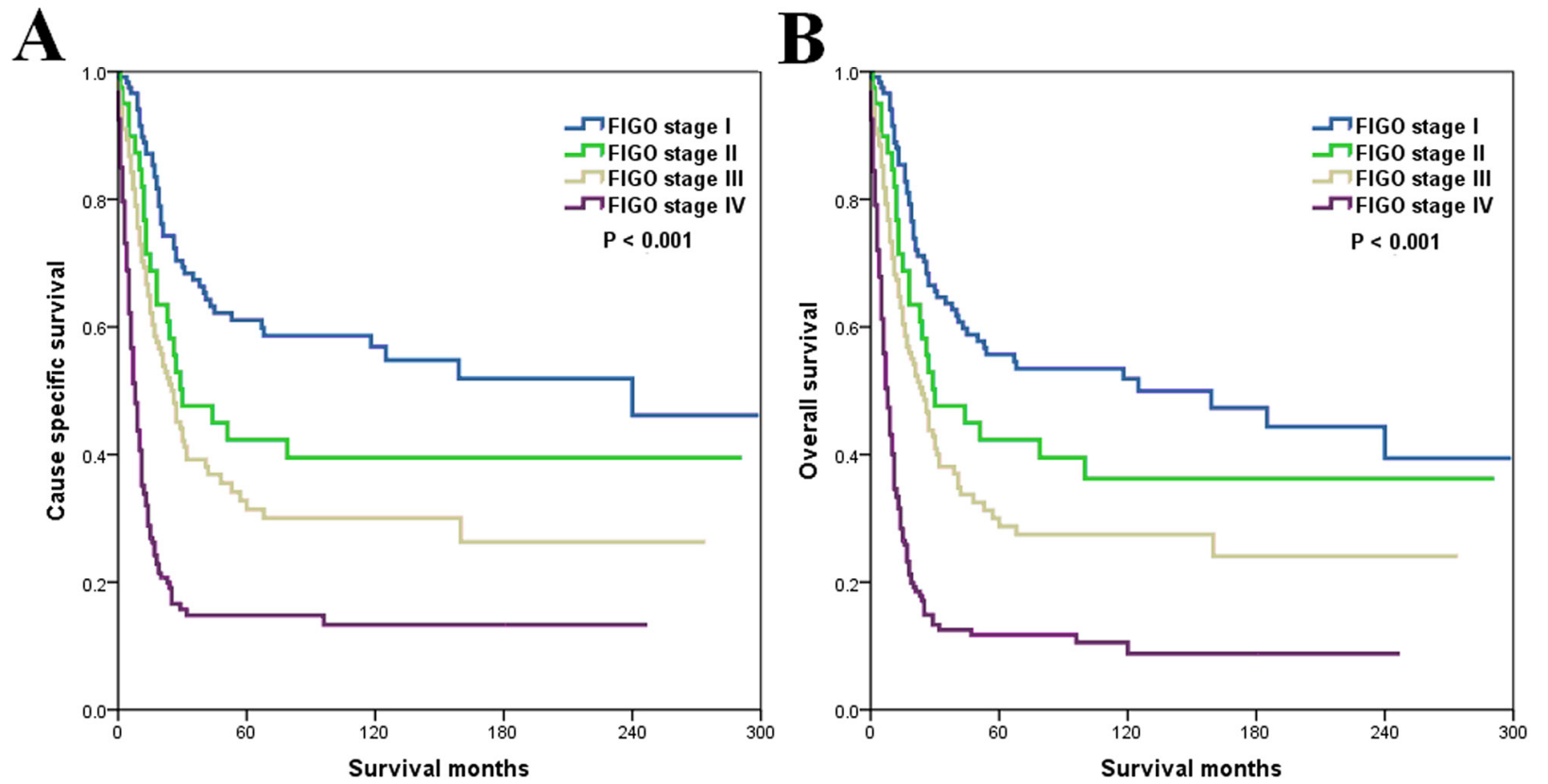

Figure 2: Cause-specific survival (A) and overall survival (B) according to International Federation of Gynaecology and Obstetrics stage. 
features, treatment trends, and survival outcomes of this rare disease using a population-based study. Second, SEER database lack of information about centralized pathologic review, pathological factors (margin status, lymphovascular invasion, and parametrial invasion), details of radiation therapy and chemotherapy, and the data of local and distant recurrence. In addition, there is little information available to guide the choice of treatment in certain patients. Although prospective studies have a greater scientific impact than retrospective studies, prospective data on the outcome of different local treatment modalities in SCCC was not available.

In conclusion, SCCC is a rare disease with aggressive characteristics and prone to metastasize and is dismal in prognosis. Reduced survival was associated with increasing age, advanced stage, and treatment by primary radiotherapy. More studies are needed to confirm our results and develop optimal management of SCCC.

\section{MATERIALS AND METHODS}

\section{Patients}

Data were obtained using SEER*Stat software (Version 8.2.1; available at http://www.seer.cancer. gov/seerstat) from the current SEER database, which is maintained by the National Cancer Institute and consists of 18 population-based cancer registries. We included SCCC patients from 1988 to 2012 and permission to access research data files was obtained [31]. The tumors were classified based on their primary site of presentation using the International Classification of Disease for Oncology, Third Edition. Data released from the SEER program did not require informed patient consent and this study was approved by the Ethics Committee of the First Affiliated Hospital of Xiamen University and the Sun YatSen University Cancer Center.

\section{Demographic and clinicopathological variables}

The following demographic and clinicopathological variables were collected from the SEER program: age, race, marital status, tumor grade, tumor size, FIGO stage, SEER stage, lymph node status, and local treatment modalities. Vital status and underlying cause of death were also were recorded.

\section{Statistical analysis}

The chi-square test and Fisher exact probability tests were used to evaluate the differences between qualitative data. Univariate and multivariate Cox proportional hazards model were used to identify prognostic factors predictive of CSS and OS. Multivariable analyses were used to identify independent prognostic factors that were significantly related to CSS and OS in univariate analyses. CSS and OS were calculated using the Kaplan-Meier method and compared using the log-rank test. The SPSS statistical software package, version 21.0 (IBM Corporation, Armonk, NY, USA) was used for statistical analysis. A value of $P<0.05$ was considered to be statistically significant.

\section{ACKNOWLEDGMENTS}

This work was supported by grants from the Natural Science Foundation of Fujian Province (No. 2015J01550), and the Foundation Medical innovation Foundation of Fujian Province (No. 2015-CXB-34).

\section{CONFLICTS OF INTEREST}

The authors declare that there are no conflicts of interest.

\section{REFERENCES}

1. Siegel RL, Miller KD, Jemal A. Cancer statistics, 2015. CA Cancer J Clin. 2015; 65:5-29.

2. Albores-Saavedra J, Gersell D, Gilks CB, Henson DE, Lindberg G, Santiago H, Scully RE, Silva E, Sobin LH, Tavassoli FJ, Travis WD, Woodruff JM. Terminology of endocrine tumors of the uterine cervix: results of a workshop sponsored by the College of American Pathologists and the National Cancer Institute. Arch Pathol Lab Med. 1997; 121:34-39.

3. Satoh T, Takei Y, Treilleux I, Devouassoux-Shisheboran M, Ledermann J, Viswanathan AN, Mahner S, Provencher DM, Mileshkin L, Åvall-Lundqvist E, Pautier P, Reed NS, Fujiwara K. Gynecologic Cancer InterGroup (GCIG) consensus review for small cell carcinoma of the cervix. Int J Gynecol Cancer. 2014 (Suppl 3); 24:S102-08.

4. Gardner GJ, Reidy-Lagunes D, Gehrig PA. Neuroendocrine tumors of the gynecologic tract: A Society of Gynecologic Oncology (SGO) clinical document. Gynecol Oncol. 2011; 122:190-98.

5. Reagan JW, Hamonic MJ, Wentz WB. Analytical study of the cells in cervical squamous-cell cancer. Lab Invest. 1957; 6:241-50.

6. Zivanovic O, Leitao MM Jr, Park KJ, Zhao H, Diaz JP, Konner J, Alektiar K, Chi DS, Abu-Rustum NR, Aghajanian C. Small cell neuroendocrine carcinoma of the cervix: analysis of outcome, recurrence pattern and the impact of platinumbased combination chemotherapy. Gynecol Oncol. 2009; 112:590-93.

7. Hoskins PJ, Swenerton KD, Pike JA, Lim P, Aquino-Parsons C, Wong F, Lee N. Small-cell carcinoma of the cervix: fourteen years of experience at a single institution using a combined-modality regimen of involved-field irradiation and platinum-based combination chemotherapy. J Clin Oncol. 2003; 21:3495-501. 
8. Cohen JG, Kapp DS, Shin JY, Urban R, Sherman AE, Chen LM, Osann K, Chan JK. Small cell carcinoma of the cervix: treatment and survival outcomes of 188 patients. Am J Obstet Gynecol. 2010; 203:347.e1-6.

9. Chan JK, Loizzi V, Burger RA, Rutgers J, Monk BJ. Prognostic factors in neuroendocrine small cell cervical carcinoma: a multivariate analysis. Cancer. 2003; 97:568-74.

10. Abeler VM, Holm R, Nesland JM, Kjørstad KE. Small cell carcinoma of the cervix. A clinicopathologic study of 26 patients. Cancer. 1994; 73:672-77.

11. Wang KL, Chang TC, Jung SM, Chen CH, Cheng YM, Wu HH, Liou WS, Hsu ST, Ou YC, Yeh LS, Lai HC, Huang CY, Chen TC, et al. Primary treatment and prognostic factors of small cell neuroendocrine carcinoma of the uterine cervix: a Taiwanese Gynecologic Oncology Group study. Eur J Cancer. 2012; 48:1484-94.

12. Lee JM, Lee KB, Nam JH, Ryu SY, Bae DS, Park JT, Kim SC, Cha SD, Kim KR, Song SY, Kang SB. Prognostic factors in FIGO stage IB-IIA small cell neuroendocrine carcinoma of the uterine cervix treated surgically: results of a multi-center retrospective Korean study. Ann Oncol. 2008; 19:321-26.

13. Dongol S, Tai Y, Shao Y, Jiang J, Kong B. A retrospective clinicopathological analysis of small-cell carcinoma of the uterine cervix. Mol Clin Oncol. 2014; 2:71-75.

14. Yuan L, Jiang H, Lu Y, Guo SW, Liu X. Prognostic Factors of Surgically Treated Early-Stage Small Cell Neuroendocrine Carcinoma of the Cervix. Int J Gynecol Cancer. 2015; 25:1315-21.

15. Chen TC, Huang HJ, Wang TY, Yang LY, Chen CH, Cheng YM, Liou WH, Hsu ST, Wen KC, Ou YC, Hung YC, Lai HC, Ho CM, Chang TC. Primary surgery versus primary radiation therapy for FIGO stages I-II small cell carcinoma of the uterine cervix: A retrospective Taiwanese Gynecologic Oncology Group study. Gynecol Oncol. 2015; 137:468-73.

16. Zhou J, Yang HY, Wu SG, He ZY, Lin HX, Sun JY, Li Q, Guo ZW. The local treatment modalities in FIGO stage I-II smallcell carcinoma of the cervix are determined by disease stage and lymph node status. Cancer Med. 2016; 5:1108-15.

17. Viswanathan AN, Deavers MT, Jhingran A, Ramirez PT, Levenback C, Eifel PJ. Small cell neuroendocrine carcinoma of the cervix: outcome and patterns of recurrence. Gynecol Oncol. 2004; 93:27-33.

18. Chen J, Macdonald OK, Gaffney DK. Incidence, mortality, and prognostic factors of small cell carcinoma of the cervix. Obstet Gynecol. 2008; 111:1394-402.

19. Lan-Fang L, Hai-Yan S, Zuo-Ming Y, Jian-Qing Z, Ya-Qing C. Small cell neuroendocrine carcinoma of the cervix: analysis of the prognosis and role of radiation therapy for 43 cases. Eur J Gynaecol Oncol. 2012; 33:68-73.

20. Intaraphet S, Kasatpibal N, Siriaunkgul S, Chandacham A, Sukpan K, Patumanond J. Prognostic factors for small cell neuroendocrine carcinoma of the uterine cervix: an institutional experience. Int J Gynecol Cancer. 2014; 24:272-79.
21. Zhou J, Chen QH, Wu SG, He ZY, Sun JY, Li FY, Lin HX, You KL. Lymph node ratio may predict the benefit of postoperative radiotherapy in node-positive cervical cancer. Oncotarget. 2016; 7:29420-28. doi: 10.18632/oncotarget.8840.

22. Zhou J, Wu SG, Sun JY, Li FY, Lin HX, Chen QH, He ZY. Comparison of clinical outcomes of squamous cell carcinoma, adenocarcinoma, and adenosquamous carcinoma of the uterine cervix after definitive radiotherapy: a population-based analysis. J Cancer Res Clin Oncol. 2017; 143:115-22.

23. Liao LM, Zhang X, Ren YF, Sun XY, Di N, Zhou N, Pan RK, Ma SH, Zhou LX. Chromogranin A (CgA) as poor prognostic factor in patients with small cell carcinoma of the cervix: results of a retrospective study of 293 patients. PLoS One. 2012; 7:e33674.

24. McCusker ME, Coté TR, Clegg LX, Tavassoli FJ. Endocrine tumors of the uterine cervix: incidence, demographics, and survival with comparison to squamous cell carcinoma. Gynecol Oncol. 2003; 88:333-39.

25. Tornesello ML, Buonaguro L, Buonaguro FM. Mutations of the TP53 gene in adenocarcinoma and squamous cell carcinoma of the cervix: a systematic review. Gynecol Oncol. 2013; 128:442-48.

26. Sheets EE, Berman ML, Hrountas CK, Liao SY, DiSaia PJ. Surgically treated, early-stage neuroendocrine small-cell cervical carcinoma. Obstet Gynecol. 1988; 71:10-14.

27. Van Nagell JR Jr, Donaldson ES, Wood EG, Maruyama Y, Utley J. Small cell cancer of the uterine cervix. Cancer. 1977; 40:2243-49.

28. Sevin BU, Method MW, Nadji M, Lu Y, Averette HA. Efficacy of radical hysterectomy as treatment for patients with small cell carcinoma of the cervix. Cancer. 1996; 77:1489-93.

29. Kuji S, Hirashima Y, Nakayama H, Nishio S, Otsuki T, Nagamitsu Y, Tanaka N, Ito K, Teramoto N, Yamada T. Diagnosis, clinicopathologic features, treatment, and prognosis of small cell carcinoma of the uterine cervix; Kansai Clinical Oncology Group/Intergroup study in Japan. Gynecol Oncol. 2013; 129:522-27.

30. McCann GA, Boutsicaris CE, Preston MM, Backes FJ, Eisenhauer EL, Fowler JM, Cohn DE, Copeland LJ, Salani R, O'Malley DM. Neuroendocrine carcinoma of the uterine cervix: the role of multimodality therapy in early-stage disease. Gynecol Oncol. 2013; 129:135-39.

31. Surveillance E, Results E. (SEER) Program (http://www. seer.cancer.gov) SEER*Stat Database: Incidence - SEER 18 Regs Research Data Hurricane Katrina Impacted Louisiana Cases, Nov 2014 Sub (1973-2012 varying) - Linked To County Attributes - Total U.S., 1969-2013 Counties, National Cancer Institute, DCCPS, Surveillance Research Program, Surveillance Systems Branch, released April 2015, based on the November 2014 submission. 